\title{
Kebijakan Penanaman Modal Asing Di Batam Tahun 2015-2017
}

\author{
Asri Wulandhari \\ Hubungan Internasional Program Magister, Universitas Muhammadiyah Yogyakarta. \\ asriwulandhari@gmail.com
}

\begin{abstract}
Abstrak
Batam merupakan gerbang masuknya investasi asing dari beberapa negara di dunia. BP Batam selaku penanggung jawab terkait masuknya investasi asing di Batam tidak hanya mengandalkan FTZ (Free Trade Zone) sebagai terobosan guna meningkatkan investasi asing di Batam. Penelitian ini bertujuan untuk menganalisis faktor-faktor apa yang menyebabkan investasi asing meningkat di tahun 2015 - 2017, dimana investasi asing di tahun 2013 - 2014 mengalami penurunan. Penelitian ini menggunakan metode kualitatif dengan teknik pengumpulan data berasal dari sumber primer dan sekunder. Hasil penelitian ini adalah membuat kebijakan investasi tahun 2013-2014 seperti melakukan Diplomatic Tour dengan menghadirkan 24 duta besar (kawasan Eropa dan Asia) dan mengadakan Business Gathering dengan pengusaha Jepang, dan menetapkan OVNI (Objek Vital Nasional Sektor Industri) dengan kawasan yang ada di Batam. Hal ini mendorong investasi asing di Batam tahun 2015-2017 semakin meningkat dengan melakukan kebijakan investasi lainnya, yaitu Deregulasi berupa FTZ dan KEK (Kawasan Ekonomi Khusus) dan Infrastruktur berupa pembangunan fisik (dibangunnya mall pelayanan publik, flyover atau jembatan layang, dan menambah jumlah waduk di Kota Batam sebagai sumber air bersih bagi masyarakat umum maupun industri) dan pembangunan non-fisik (membentuk program dari BKPM pusat yang dilanjutkan oleh BP Batam, yaitu KLIK (Kemudahan Investasi Langsung Konstruksi) i23J (Izin Investasi 3 Jam) ).
\end{abstract}

Kata Kunci : Kebijakan, Penanaman Modal Asing, Batam, Tahun 2015-2017.

\section{Foreign Investment Policy In Batam 2015-2017}

\begin{abstract}
Batam is a gateway for investment in state-owned countries in the world. BP Batam as the responsible party for the entry of foreign investment in Batam does not only rely on FTZ (Free Trade Zone) as a breakthrough to increase foreign investment in Batam. This study aims to improve the factors that cause foreign investment to increase in 2015 - 2017, where foreign investment in 2013 - 2014 increases. This research uses a qualitative method with data collection techniques obtained from primary and secondary sources. The results are making investment policies in 2013-2014 such as conducting Diplomatic Tours by presenting 24 ambassadors (European and Asian regions) and, holding Business Meetings with Japanese entrepreneurs, and gathering OVNI (National Vital Objects of the Industrial Sector) with existing regions in Batam. This has led to increased foreign investment in Batam in 2015-2017 by making new investments, namely Deregulation of the FTZ and KEK (Special Economic Zones); and Infrastructure consists of physical development (construction of public service malls, flyovers or overpasses, and the addition of dams (dams) in Batam as a source of clean air for the general public industry) and non-physical development (making programs from BKPM BP Batam, i.e. KLIK (Ease of Direct Investment Construction) i23J (3 Hours Investment License)).
\end{abstract}

Keywords: Policy, Foreign Investment, Batam, 2015-2017.

\section{PENDAHULUAN}

Upaya dalam meningkatkan kesejahteraan, pembangunan dan kemakmuran rakyat yang lebih baik akan selalu dilakukan oleh setiap negara. Setiap negara selalu memiliki cara yang berbeda dalam melakukan upaya peningkatan tersebut, seperti menarik sebanyak mungkin investasi asing masuk ke negaranya. Dalam melakukan penarikan investasi masuk sebanyak mungkin ke dalam suatu negara, pembangunan nasional harus diarahkan ke 
bidang industri. Terdapat asumsi bahwa investasi berperan penting dalam mendorong pertumbuhan ekonomi suatu negara. Dalam mengarahkan hal tersebut, minimnya modal dan teknologi yang menjadi suatu dasar untuk menuju industrialisasi menjadi suatu permasalahan yang memang sejak awal telah dihadapi oleh negara-negara tersebut. Satu-satunya cara dalam mengatasi permasalahan tersebut adalah dengan mengundang masuknya modal asing dari beberapa negara maju ke negara-negara berkembang, seperti Indonesia.

Indonesia merupakan salah satu negara yang sedang berkembang, serta butuh adanya modal atau investasi dalam jumlah besar. Sejak dikeluarkannya Undang-Undang Nomor 1 Tahun 1967 tentang Penanaman Modal Asing (PMA) dan Undang-Undang Nomor 6 Tahun 1968 tentang Penanaman Modal Dalam Negeri (PMDN), maka sejak itu pula kegiatan penanaman modal di Indonesia telah dimulai. Harapannya adalah agar investor domestik maupun asing dapat menanamkan investasinya di Indonesia. Iklim investasi yang bersifat kondusif sangat mempengaruhi penarikan arus modal negara. Iklim tersebut meliputi aturan kelembagaan dan lingkungan dalam situasi kini maupun nanti, yang juga mampu mempengaruhi tingkat pengembalian dan resiko suatu investasi.

Batam merupakan gerbang masuknya investasi, baik lokal maupun asing di Provinsi Kepulauan Riau di Indonesia. Batam juga merupakan pelayan bagi pelaku investasi luar maupun dalam negeri, yang akan menanamkan modalnya di Batam. Ketertarikan investor pada Batam dalam berinvestasi adalah karena keunggulan yang Batam miliki, baik secara geografis yang berbatasan langsung dengan Singapura dan Malaysia, maupun ekonomi, yang menjadi salah satu daerah di Indonesia yang tidak pernah mengalami krisis ekonomi. ${ }^{1}$ Batam adalah suatu kawasan yang merupakan kawasan perdagangan bebas. Sehingga, perusahaan dengan orientasi ekspor akan diuntungkan bila melangsungkan usahanya di Batam. Ditambah lagi, Batam berjarak dengan Singapura hanya sekitar $20 \mathrm{~km}$, sehingga akses terhadap finansial global tentunya akan lebih mudah. Selain itu, ditetapkannya Batam sebagai daerah FTZ (Free Trade Zone) melalui Peraturan Pemerintah No 46 Tahun 2007 tentang Kawasan Perdagangan Bebas dan Pelabuhan Bebas Batam (KPBPB), mampu menjadikannya terobosan baru guna meningkatkan daya saing regional dan dinamika global serta mendorong tumbuhnya investasi ${ }^{2}$. Sejak FTZ ditetapkan di Batam, Pemerintah Pusat telah menetapkan Badan Pengusahaan Kawasan Perdagangan Bebas Dan Pelabuhan Bebas Batam atau yang lebih dikenal dengan Badan Pengusahaan (BP) Batam untuk bertanggung jawab terhadap pelaksanaan kebijakan Free Trade Zone. Selain memberikan kepastian hukum kepada para investor selama itu untuk berinvestasi di Batam, BP Batam berupaya memanfaatkan momentum tersebut untuk dapat meningkatkan daya saing Batam agar dapat menarik investor asing ke Indonesia.

Namun, upaya BP Batam selaku pemerintah pusat yang bertugas mempromosikan Kota Batam ke dalam maupun luar negeri,dalam menarik investor, khususnya investor asing ke Batam, tidaklah selalu mudah bila hanya mengandalkan terobosan tersebut. Selain kelemahan insfrastruktur, proses perizinan yang kurang mendukung investasi karena untuk memperoleh izin terbilang lama di tahun 2015. Isu perizinan menjadi sangat krusial di pulau berbasis investasi seperti Batam. Calon investor menuntut kepastian, sehingga hal tersebut menjadi kendala utama, dan mengakibatkan hilangnya keunggulan kompetitif dan Batam kalah bersaing dengan kawasan industri lain, seperti Penang dan Johor Baru di Malaysia yang justru mengalami kemajuan. Sekitar tahun 2015 dan 2016 terdapat 110 perusahaan asing di Batam telah berhenti beroperasi. Tren ini makin terus berlanjut dengan adanya 53 perusahaan menyusul berhenti beroperasi di awal tahun $2017 .^{3}$

Dalam upaya mencapai tujuan pengembangan Batam sebagai daerah industri, prasyarat utama yang harus dipenuhi adalah pembangunan fisik dan non-fisik. Pembangunan fisik untuk memudahkan kelancaran investasi berupa insfrastruktur (jalan, jembatan, pelabuhan laut, bandara, waduk, dsb). Sedangkan pembangunan non-fisik dilakukan untuk menarik minat investor, berupa kemudahan fasilitas. Hal ini berdasarkan pada peraturan Kepala Badan Pengusahaan Kawasan Perdagangan Bebas dan Pelabuhan Bebas Batam (BP Batam) Nomor 10 Tahun 2011 tanggal 21 September 2011 tentang tugas dan fungsi BP Batam. Tugas tersebut yaitu melaksanakan pengelolaan, pengembangan, dan pembangunan di Kawasan Perdagangan Bebas dan Pelabuhan Bebas Batam (Kawasan Batam). Sementara, salah satu fungsinya adalah melaksanakan pengelolaan kegiatan

\footnotetext{
${ }^{1}$ Kuncoro, M. 2005. "Menanti Reformasi Iklim Bisnis Indonesia”. Jurnal Ilmu-Ilmu Sosial-UNISIA, No. 55/XXVIII/I/2005

${ }^{2}$ Ibid.

${ }^{3}$ Purba, D. 2018. Faktor Dominan Penurunan Pertumbuhan Ekonomi Batam. Seminar Nasional Ilmu Sosial dan Teknologi (SNISTEK) 1, 23 Agustus 2018. Batam. Indonesia.
} 
penanaman modal. ${ }^{4}$ Karenanya, jajaran pimpinan BP Batam sempat diganti oleh Kemenko Perekonomian dari arahan Presiden dengan menugaskan pimpinan BP Batam yang baru untuk meningkatkan lebih lagi Penanaman Modal Asing (PMA) di Batam dengan berbagai macam pembenahan agar mampu bersaing dengan dengan daerah lain yang memiliki status yang sama dengan Batam.

Realisasi investasi PMA di Batam berdasarkan LKPM 2015 - 2017 yang diterbitkan oleh Pusat Pengelolaan Data dan Sistem Informasi (PDSI) BP Batam ${ }^{5}$, nilai dari setiap tahun nya mengalami peningkatan yang signifikan.

Peningkatan investasi PMA di Batam dari tahun 2015-2017 mengalami peningkatan. Pada tahun 2015, investasi asing sekitar US\$ 291.46 juta terbagi menjadi US\$ 163.00 juta untuk perusahaan asing baru dan US\$ 128.46 juta perluasan usaha/ekspansi. Kemudian meningkat di tahun 2016, yaitu US\$ 463,73 juta terbagi menjadi US\$ 295.31 juta untuk perusahaan asing baru dan US\$ 168.42 juta perluasan usaha/ekspansi. Makin meningkat di tahun 2017, yaitu US\$ 618.74 juta yang terbagi menjadi US\$ 452.86 juta untuk perusahaan asing baru dan US\$ 165.88 juta perluasan usaha/ekspansi . Selain itu, ekspansi atau perluasan usahaterbilang stabil. Meningkatnya investasi asing di Batam dari rentang waktu 2016-2017 ditandai dengan adanya lebih dari 700 perusaahan asing yang beroperasi ${ }^{6}$ dan tersebar di 22 kawasan industri di Kota Batam. Dari grafik yang dipaparkan tersebut, dapat dilihat bahwa fakta yang ada adalah terdapat faktor-fakor yang menjadi penyebab meningkatnya investasi asing di Batam dari tahun 2015-2017. Data di atas mencakup beberapa sektor, seperti sektor pariwisata dan industri.

Di tahun 2013, nilai realisasi investasi asing di Batam adalah sekitar US\$ 156.21 juta dan US\$ 187.13 juta di tahun 2014. Dari ke dua tahun tersebut, nilai realisasi investasi asing di Batam dapat dikatakan sangat rendah. Namun, mulai meningkat di tahun-tahun berikutnya, yaitu tahun 2015 hingga 2017. Dengan demikian, beberapa hal di atas mendorong peneliti untuk melakukan penelitian lebih lanjut untuk mengetahui faktor-faktor apa yang menyebabkan investasi asing di Batam meningkat tahun 2015-2017 dan menjadikannya suatu permasalahan yang akan dibahas dalam penelitian ini.

\section{KERANGKA PEMIKIRAN}

\section{Teori Otonomi Daerah}

Secara etimologi, berdasarkan Kamus Besar Bahasa Indonesia, otonomi adalah pola pemerintahan sendiri. Sedangkan, otonomi daerah adalah hak, wewenang dan kewajiban daerah untuk mengatur dan mengurus rumah tangganya sendiri sesuai dengan peraturan perundang-undangan yang berlaku. Widjaja (2005) mengatakan bahwa Daerah Otonomi adalah Daerah yang memiliki kewenangan dalam membuat kebijakan daerah untuk memberi pelayanan, peningkatan peranan serta, prakarsa dan pemberdayaan masyarakat yang bertujuan pada peningkatan kesejahteraan rakyat. ${ }^{7}$ Menurut Bagir (2002) ${ }^{8}$ mendefinisikan otonomi merupakan sebuah tatanan ketatanegaraan, bukan hanya tatanan Negara administrasi Negara. Menurut Undang-Undang No. 32 Tahun 2004, daerah otonom adalah kesatuan masyarakat hukum yang memiliki batas-batas wilayah yang berwenang mengatur dan mengurus urusan pemerintahan dan kepentingan masyarakat setempat menurut prakarsa sendiri berdasarkan aspirasi masyarakat dalam sistem Negara Kesatuan Republik Indonesia.

Dalam kerangka konsep otonomi daerah, status kota Batam sebagai zona bebas dimengerti sebagai fasilitas istimewa kepabeanan dan perpajakan (customs and tax privileged facility) yang diberikan pemerintah pusat kepada kota Batam. Hal ini dimungkinkan oleh kewenangan pemerintah pusat dalam bidang moneter dan fiskal, sesuai Ayat (1), Pasal 7, UU No.22/1999. Pada dasarnya fasilitas istimewa tersebut diberikan sesuai dengan semangat yang mendasari penyelenggaraan otonomi daerah yang memperhatikan prinsip-prinsip potensi

\footnotetext{
${ }^{4}$ Badan Pengusahaan Kawasan Perdagangan Bebas dan Pelabuhan Bebas Batam (BP Batam) Nomor 10 Tahun 2011 tanggal 21 September 2011 tentang tugas dan fungsi BP Batam. Diakses di https://bpbatam.go.id/pages/read/52-tugas-dan-fungsi pada 20 September 2019.

${ }_{5}^{5}$ Pusat Pengelolaan Data dan Sistem Informasi (PDSI) BP Batam. Batam Indonesia Free Trade Zone Authority BP Batam. Tahun 2018. Edisi II Vol. XXXIV. Hlm. 10

${ }^{6}$ Ibid.

${ }^{7}$ HAW Widjaja. 2005. Penyelenggaraan Otonomi di Indonesia Dalam Rangka Sosialisasi Undang-Undang Nomor 32 Tahun 2004 tentang Pemerintahan Daerah. Jakarta: Raja Grafindo, hlm. 133.

${ }^{8}$ Bagir Manan.2002. Pemerintahan Daerah Bagian I. Penerbit Penataan Administratif Organisation Planning. UGM. Yogyakarta.
} 
dan keanekaragaman daerah. Dalam hal ini keunggulan lokal wilayah kota Batam (sesuai UU No.53/1999). Dalam kerangka konsep Negara Kesatuan Republik Indonesia, fasilitas yang diberikan pemerintah pusat kepada kota Batam adalah bagian dari instrumen dan mekanisme pengembangan ekonomi nasional, yang antara lain meliputi perencanaan dan pengendalian pembangunan nasional secara mikro. Hal ini dimungkinkan oleh kewenangan yang dimiliki pemerintah pusat dalam bidang lain, sesuai Ayat (2) Pasal 7 UU No.22/1999.

Status kota Batam sebagai zona bebas tidak bertentangan dengan jiwa otonomi daerah sepanjang penerapan status tersebut tidak mengabaikan prinsip-prinsip otoritas daerah otonomi kota Batam untuk mengurus dan mengatur kepentingan masyarakat setempat menurut prakarsa sendiri berdasarkan aspirasi msyarakat sesuai dengan peraturan perundang-undangan. Kota Batam sebagai zona bebas adalah perpaduan antara kepentingan pemerintah pusat (dalam kerangka konsep Negara Kesatuan Republik Indonesia) dan kepentingan masyarakat Batam (dalam konsep kerangka konsep otonomi daerah), pada bidang dan kewenangan masing-masing.

\section{Konsep Infrastruktur}

Sejauh ini, belum ada kesepakatan mengenai definisi dari infrastruktur. Definisi infrastruktur dalam Kamus Besar Bahasa Indonesia dapat diartikan sebagai sarana dan prasarana umum. Secara umum diketahui sebagai fasilitas berupa jalan, rumah sakit, jembatan, sanitasi dan sebagainya. Menurut ekonomi infrastruktur adalah wujud dari public capital (modal publik) yang dibentuk dari investasi yang dilakukan oleh pemerintah. Infrastruktur dalam penelitian ini meliputi jalan, jembatan, dan sistem saluran pembuangan ${ }^{9}$.

Menurut Grigg $(1998)^{10}$, infrastruktur adalah sistem fisik yang menyediakan transportasi, pengairan, drainase, bangunan gedung, fasilitas publik lainnya, yang diperlukan guna memenuhi kebutuhan dasar manusia, baik kebutuhan sosial maupun kebutuhan ekonomi. Dalam hal ini, hal-hal yang berkaitan dengan infrastruktur tidak dapat dipisahkan. Sistem lingkungan dapat terhubung karena adanya infrastruktur yang menopang antara tatanan sosial dan ekonomi. Ketersediaan infrastruktur memberikan dampak terhadap sistem sosial dan sistem ekonomi yang ada dalam lingkungan masyarakat. Maka infrastruktur perlu dipahami sebagai dasar-dasar dalam mengambil kebijakan ${ }^{11}$.

Pembangunan terdiri dari pembangunan fisik dan non-fisik. Menurut Kuncoro (2010) ${ }^{12}$ pembangunan fisik adalah pembangunan yang dapat dirasakan langsung oleh masyarakat atau pembangunan yang tampak oleh mata misalnya berupa infrastruktur, bangunan dan fasilitas umum. Sedangkan pembangunan non-fisik menurut Wresniwiro (2012) adalah jenis pembangunan yang tercipta oleh dorongan masyarakat setempat dan memiliki jangka waktu yang lama, misalnya kemudahan fasilitas. ${ }^{13}$

Sehubungan dalam penelitian ini, infrastruktur yang ada di Kota Batam dari tahun ke tahun, utamanya 2015-2017 terus ditambah dan diperbaiki. Mengingat Kota Batam adalah salah satu tujuan berinvestasi terbesar di Indonesia, dan salah satu kendala investor asing dalam berinvestasi di Batam adalah minimnya infrastruktur, maka pemerintah terus meningkatkan kualitas infrastruktur di Kota Batam. Adapun peningkatan dan perbaikan infrastruktur tersebut mencakup sosial dan ekonomi, dimana infrastruktur mampu meberikan dampak langsung mengenai penurunan maupun peningkatan investasi asing.

\section{Konsep Penanaman Modal Asing atau Investasi Asing}

Berdasarkan pengertian Fitzgerald ${ }^{14}$, konsep investasi asing dipahami sebagai suatu aktifitas yang berkaitan dengan usaha penarikan sumber-sumber dana yang akan digunakan untuk mengadakan barang modal pada saat ini dimana nantinya barang modal tersebut akan dihasilkan pada masa yang akan datang dengan mengeluarkan barang modal melalui produk yang baru.

\footnotetext{
${ }^{9}$ Mankiw, N. Gregory. 2003. Teori Makro Ekonomi. Jakarta : Erlangga.

${ }^{10}$ Grigg, N. 1998. Infrastructure Engineering and Management. John Wiley \& Sons.

${ }^{11}$ Kodoatie, Robert J. 2005. Pengantar Manajemen Infrastruktur. Pustaka Pelajar : Yogyakarta.

${ }^{12}$ Kuncoro, Mudrajat. 2010. Dasar-Dasar Ekonomika Pembangunan, UPP STIM YKPN Yogyakarta.

${ }^{13}$ Wresniwiro. 2012. Membangun Republik Desa. Jakarta. Visimedia.

${ }^{14}$ Fitzgerald, E.V.K, 1978. Public Sector Investment Planning for Developing Country. First Edition, The MacMillan India Press Ltd, Madras.
} 
Dalam buku Krugman \& Obsfeld ${ }^{15}$, Penanaman Modal Asing merupakan aliran modal internasional dimana suatu perusahaan di suatu negara mendirikan atau memperluas cabang perusahaan di negara lain. PMA dapat berupa greenfield, yaitu dengan membuka pabrik baru atau cabang perusahaan baru di negara lain, merger dengan perusahaan asing maupun dengan mengakuisisi perusahaan asing maupun domestik yang sudah ada di negara lain.

Dalam jurnal Maria Timbernian yang berjudul Peran Pemerintah Kota Bitung dalam Peningkatan Investasi Asing di Sektor Pariwisata ${ }^{16}$ disebutkan bahwa UU No.25 Tahun 2007 mencakup poin penting dalam mengatasi masalah serius yang kerap kali dihadapi calon investor yang akan melakukan kegiatan penanaman modal di Indonesia. Bab 1 Pasal 1 ayat 10 mencantumkan hal tentang Pelayanan Terpadu Satu Pintu (PTSP) yakni kegiatan penyelenggaraan suatu perizinan dan non perizinan yang mendapat pendelegasian atau limpahan wewenang dari lembaga atau instansi yang memiiki kewenangan perizinan dan non perizinan yang proses pengelolaannya dimulai dari tahap permohonan sampai dengan tahap terbitnya dokumen dilakukan dalam satu tempat.

Menurut jurnal tersebut, sistem pelayanan satu atap ini diharapkan dapat mengakomodasi keinginan calon investor/pengusaha untuk memperoleh pelayanan yang lebih efisien, mudah dan cepat. Calon investor yang akan melakukan kegiatan penanaman modal di Indonesia kemudian tidak membutuhkan waktu lama untuk memperoleh izin usaha. Selain itu, calon investor juga dimudahkan karena tidak perlu mengeluarkan biaya tambahan karena adanya biaya pajak maupun pungutan lainnya yang dapat membengkak dari tarif resmi akibat panjangnya jalur birokrasi yang harus ditempuh untuk memperoleh izin usaha. Berkaitan dengan itu, menurut kasus dalam penelitian ini, investasi asing adalah salah satu unsur penggerak penting guna meningkatkan perekonomian dan melakukan pembangunan di daerah, utamanya di Kota Batam. Beberapa potensi yang dimiliki Kota Batam hanya dapat digerakkan secara maksimal melalui adanya dukungan dari investasi, utamanya investasi asing. Dalam berinvestasi di Batam, proses perizinan bagi investor asing adalah salah satu hal yang krusial. Dengan demikian, BP Batam terus mengupayakan agar investor mudah dalam melakukan proses perizinan.

\section{HASIL PEMBAHASAN}

\section{Kebijakan Investasi Tahun 2013-2014}

\section{a. Arah Kebijakan Investasi}

1) Upaya Promosi Kegiatan Penanaman Modal

Langkah kebijakan yang diambil pemerintah adalah salah satu upaya dalam menarik investor asing ke Batam. Promosi yang dilakukan oleh BP Batam pun dilakukan secara maksimal dengan membentuk berbagai macam program, salah satu nya adalah program Diplomatic Tour. Program ini adalah salah satu upaya promosi potensi daerah yang dilaksanakan pada tahun 2012 atas kerjasama dengan Kementerian Luar Negeri RI dengan pemerintah Daerah Provinsi Kepulauan Riau. Program ini dihadiri oleh 24 duta besar, seperti dari kawasan Eropa dan Asia , serta 9 korps Diplomatik lainnya. Adapun dampak dari terlaksananya Diplomatic Tour ini adalah peningkatan jumlah investor asing di Batam yang kemudian memberikan peluang lapangan pekerjaan hingga di tahun 2013.

2) Strategi Investasi

Upaya pemerintah dalam menjaga iklim investasi agar tetap kondusif, maka perlu dilakukan adanya evaluasi antara instansi yang mengurusi permasalahan investasi asing, yaitu BP Batam dengan investor. Seperti diadakannya Business Gathering dengan pengusaha Jepang yang berinvestasi di Batam pada tahun 2013. Dalam mengadakan Business Gathering tersebut menghadirkan pula narasumber, seperti Kepala BKPM RI, Dirjend Pajak RI, Dirjend Bea dan Cukai RI, Kapolri Kepri, dan Kepala Imigrasi Batam.

Berdasarkan Surat Keputusan (SK) Kementerian Perindustrian No. 620 tahun 2012, menetapkan OVNI (Objek Vital Nasional Sektor Industri) dengan kawasan yang ada di Batam. Sehingga, kegiatan produksi

\footnotetext{
${ }^{15}$ Krugman and Obsfeld. 2003. International Economics, Theory and Policy. Sixth Edition. Boston.

${ }^{16}$ E Journal Unsrat. Peran Pemerintah Kota Bitung dalam Peningkatan Investasi Asing di Sektor Pariwisata. http://www.ejournal.unsrat.ac.id/index.php/polotico/article/download/10310 diakses pada 19 September 2019.
} 
industri dapat berjalan dengan lancar dan aman. Hal ini dimuat dalam lampiran Keputusan Menteri Perindustrian Republik Indonesia No. 466 Tahun 2014.

3) Simplifikasi Pelayanan Kegiatan Investasi

Simplifikasi (deregulasi) dalam kegiatan ekonomi memudahkan usaha dari para pelaku ekonomi, karena dianggap sebagai salah satu upaya untuk meningkatkan efisiensi bagi para pelaku ekonomi. Adapun langkahlangkah yang diambil oleh pemerintah dalam kegiatan investasi, baik dalam maupun luar negeri melalui beragam paket kebijakan. Seiring dengan pelaksanaan otonomi daerah, pemerintah gencar melakukan penyempurnaan terkait pelayanan kegiatan investasi guna memudahkan calon investor melakukan kegiatan investasi.

Dari ketiga arah kebijakan investasi yang dipaparkan di atas, membuat nilai realisasi investasi asing di Batam meningkat perlahan demi perlahan. Bab I pada penelitian ini menunjukkan secara singkat mengenai nilai realisasi investasi asing di Batam di tahun 2013 dan tahun 2014 dapat dikatakan sangat rendah. Pemaparan terkait ketiga arah kebijakan investasi tersebut merupakan tahapan meningkatkan investasi asing di tahun 20132014 yang dilakukan pemerintah pusat dan pemerintah daerah, yaitu BP Batam. Kemudian, mulai meningkat perlahan di tahun-tahun berikut nya, yaitu tahun 2015 hingga tahun 2017. Dalam hal ini, terdapat beberapa faktor yang menjadi penyebab meningkatnya investasi asing di Batam tahun 2015-2017.

\section{Deregulasi}

Secara resmi di awal tahun 2018, Bank Dunia telah merilis peringkat kemudahan berusaha (Ease of Doing Business/ EoDB) negara-negara di dunia untuk tahun 2017. Hal ini menjadi salah satu indikator yang diperoleh dari sejumlah aspek dan berpengaruh pada keputusan dari para investor dalam menanamkan modalnya di suatu negara. Semakin baik kemudahan berusaha menunjukkan bahwa semakin efisiensi pasar dari suatu negara tersebut bekerja dan iklim investasi dikatakan semakin baik. Dalam mendukung pemerintah untuk terus memperbaiki iklim investasi di Indonesia, Presiden Joko Widodo telah menekan Peraturan Presiden No. 91 Tahun 2017 Tentang Percepatan Pelaksanaan Berusaha pada akhir tahun lalu. Presiden memberikan amanat dalam Peraturan Presiden tersebut untuk membetuk Satuan Tugas Nasional, Kementerian/Lembaga, Provinsi, hingga Kabupaten/Kota guna mempercepat pembentukan iklim investasi yang baik. ${ }^{17}$

Berdasarkan Keputusan Presiden No.74 Tahun 1971 Tentang Pengembangan Pembangunan Pulau Batam dikelola dibawah Badan Otorita Batam, atau yang dikenal saat ini adalah Badan Pengusahaan Batam (BP Batam). Seiring dengan perkembangan industri di Batam, Keputusan Presiden No.41 Tahun 1973 Batam ditetapkan sebagai Daerah Industri Pulau Batam. Kemudian, diikuti dengan Keputusan Presdien No.33 Tahun 1974 Tentang Penunjukan dan Penetapan beberapa wilayah usaha Bounded House.

Batam dikenal sebagai daerah tujuan investasi bagi investor asing pada tahun 1984 karena letaknya yang strategis, yaitu berada di jalur lalu lintas perdagangan internasional Selat Malaka yang merupakan jalur perdagangan internasional tersibuk kedua setelah Selat Dover di Inggris. Sehingga, pemerintah Indonesia pada saat itu membentuk Batam sebagai model penanaman modal atau investasi. Adapun negara yang paling mendominasi adalah dari Singapura, dikarenakan terbatasnya lahan yang dimiliki Singapura dalam mengembangkan industrinya sehingga Batam mampu menampung para investor asing. Batam, memiliki dua pilihan fasilitas investasi, yaitu FTZ (Free Trade Zone) dan KEK (Kawasan Ekonomi Khusus).

\section{a. Free Trade Zone (FTZ)}

Free Trade Zone (FTZ) atau Zona Perdagangan Bebas diistilahkan sebagai salah satu bentuk dari sektor ekonomi yang dipandang sebagai dismilaritas sudut pandang. Sementara, perdagangan bebas diistilahkan sebagai konsep politik yang mengandaikan berlakunya sistem perdagangan internasional yang disetujui oleh pemerintah sesuai negara, baik terkait dengan pengenaan tarif (hambatan tarif) ataupun nir-tarif (bukan hambatan tarif/non-tarif). ${ }^{18}$

Secara resmi, Pemerintah menerbitkan Peraturan Pemerintah (PP) No. 2/2009 tentang perlakuan kepabeanan, perpajakan, dan cukai serta pengawasan atas pemasukan dan pengeluaran barang di kawasan perdagangan bebas. Hal tersebut diresmikan pada 20 Januari 2009, tepatnya setelah Presiden SBY

\footnotetext{
${ }^{17}$ MEDIA KEUANGAN. Transparansi Informasi Kebijakan Fiskal. 2018. Vol. XIII/No.128. diakses dari https://www.kemenkeu.go.id/media/9830/media-keuangan-mei-2018.pdf

${ }^{18}$ Muliono, Heri. Op. Cit., halaman 117-118.
} 
meresmikan FTZ Batam-Bintan-Karimun (BBK) di Batam. Peraturan Pemerintah yang diresmikan ini menuai kontroversi dari sejumlah kalangan yang menganggap dasar hukum penerbitan peraturan tersebut hingga isi PP tersebut bertentangan dengan semangat FTZ. Sehingga, menimbulkan berbagai opini agar PP 02 dibatalkan dengan alasan hukum. Namun, pemerintah memegang kendali dengan menerbitkan tiga Peraturan Menteri Keuangan No. 45, 46, 47 yang berisi petunjuk pelaksanaan kepabeanan dan perpajakan di wilayah FTZ pada April 2009.

Seiring dengan perkembangan Batam sebagai kawasan industri yang didukung dengan ketersediaan sarana dan prasarana, status Batam dari Bounded Zone Plus menjadi Free Trade Zone (FTZ). FTZ di Batam telah diterapkan secara efektif di tahun 2007 melalui Peraturan Pemerintah No 46 Tahun 2007 tentang Kawasan Perdagangan Bebas dan Pelabuhan Bebas Batam (KPBPB). Tujuan dari pembentukan FTZ ini adalah untuk meningkatkan investasi pada suatu daerah, dimana bea dan kuota dihapuskan dan kebutuhan untuk birokrasi ditekan rendah guna menarik perusahaan-perusahaan dengan menambahkan intensif kegiatan usaha. Pemerintah Pusat memberikan empat (4) keunggulan yang tercantum dalam Undang-Undang Pelabuhan Bebas dan Perdagangan Bebas, yaitu:

1). Bebas Pajak Pertambahan Nilai (PPN)

2). Pajak Pertambahan Nilai Barang Mewah (PPN-BM)

3). Bea Masuk

4). Bea Keluar

Menurut Bapak Edy Putra Irawady ${ }^{19}$, kepala BP Batam dalam suatu media cetak mengatakan bahwa bila investor menggunakan fasilitas FTZ ini, maka barang yang dihasilkan harus dikespor ke luar negeri. Hal tersebut dikarenakan FTZ orientasinya adalah ekspor. ${ }^{20}$

Setelah peresmian PP No. 2/2009 oleh Presiden SBY, masih ada sebagian kalangan yang memandang bahwa penerapan FTZ-BBK belum berjalan baik. Hal ini dikarenakan bukan hanya dipengaruhi oleh kondisi pergerakan ekonomi global, namun pelaksanaan FTZ dianggap masih memiliki kendala akibat peresmian PP No. 2 /2009. Adanya perbedaan interpretasi hukum yang dianggap pelaku industri bahwa PP tersebut telah menimbulkan gangguan dalam proses kelancaran arus keluar masuk barang ke FTZ Batam. Isu mendasar yang sering diperdebatkan lainnya adalah terkait makna dari perdagangan bebas yang diatur daam UndangUndang No. 44/2007 tentang Kawasan Perdagangan Bebas dan Pelabuhan Bebas. Kawasan Perdagangan Bebas terpisah dari kawasan pabean, meskipun masih berada dalam wilayah Negara Indonesia. Disisi lain, pemerintah telah meresmikan Peraturan Pemerintah tentang kepabeanan dan perpajakan plus pengawasan keluar masuk. Kedua argumen berbeda tersebutlah yang membuat implementasi FTZ di Batam belum menunjukkan hasil yang baik sejak 1 April 2009.

Ide pembentukan FTZ telah dicanangkan oleh Pemerintah Daerah maupun para pengusaha Batam dengan mengajukannya lebih dahulu kepada Pemerintah Pusat. Namun demikian, perubahan ketentuan mungkin saja terjadi dikarenakan adanya aturan pemerintahan yang seiring waktu berubah. Hal ini disebabkan pengembangan Batam masih mendasar pada KEPRES maupun Peraturan Pemerintah ataupu Keputusan Menteri. Di sisi lain, investor sangat memerlukan adanya kepastian hukum, uatamanya di bidang regulasi maupun birokrasi dengan mempertimbangkan jangka waktu panjang atau pendeknya bagi pelaku usaha dalam berinvestasi. Sehingga, kepastian di bidang perundang-undangan diperlukan guna melindungi investasinya.

Beralih dari era FTZ, muncullah ide pembentukan fasilitas pilihan investasi lainnya, yaitu KEK (Kawasan Ekonomi Khusus) atau SEZ (Special Economic Zone). Adanya ide pembentukan KEK ini didasari karena perdebatan dari sejumlah kalangan tersebut.

\section{b. Kawasan Ekonomi Khusus (KEK)}

KEK atau SEZ (Special Economic Zone) merupakan strategi dalam menarik investasi serta meningkatkan daya saing perdagangan internasional. KEK hampir sama dengan FTZ, perbedaannya adalah bahwa KEK memiliki skala yang lebih kecil. Menurut Bapak Edy, KEK adalah pilihan fasilitas invetasi selain FTZ dimana bila investor berinvestasi melalui KEK barang yang dihasilkan dapat dikirim terlebih dahulu ke

\footnotetext{
${ }^{19}$ Edy Putra Irawady. Kepala BP Batam tahun 2019. Sarjana S1 bidang Hukum dari UI (1981). Meraih gelar Master of Arts in International Graduate Transaction dari George Mason University, Amerika Serikat.

${ }^{20}$ Investor Punya dua Pilihan Fasilitas investasi di Batam. https://www.aa.com.tr/id/ekonomi/investor-punyadua-pilihan-fasilitas-investasi-di-batam/1409492
} 
wilayah lain dalam negeri. Tujuannya adalah sama, yaitu meningkatkan investasi pada suatu daerah dalam suatu negara. Beberapa negera di dunia telah menerapkan KEK, seperti RRC, India, Jordania, Rolandia, Kazakhstan, Filipina dan Rusia.

Rencana penerapan dan pengembangan KEK merupakan kebijakan pemerintah yang didengungkan pada tahun 2006 guna menggairahkan kembali iklim investasi di Indonesia. Batam, Kepulauan Riau, Indonesia adalah salah satu kota yang dijadikan sebagai kawasan KEK. KEK adalah suatu rancangan atau konsep kerjasama Pemerintah Indonesia dengan Pemerintah Singapura, atau yang dikenal dengan $G$ to $G$ (Government to Government). Tujuan KEK adalah sebagai kawasan dengan batas tertentu dalam wilayah NKRI guna menyelenggarakan fungsi perekonomian yang bersifat khusus dan memperoleh fasilutas tertentu.

Berdasarkan PP No. 96 Tahun 2015 Tentang Fasilitas dan Kemudahan di Kawasan Ekonomi Khusus, terdapat 14 poin fasilitas dan kemudahan yang tersedia dalam KEK. Diantaranya :

1). Investment Allowance

2). Amortisasi dipercepat

3). Pajak Dividen

4). Kompensasi kerugian yang lebih lama

5). Tax Holiday

6). Fasilitas Pembebasan PPh Pasal 22 impor

7). PPN impor tidak dipungut

8). PPN pembelian dalam negeri tidak dipungut

9). Pembebasan PPN dan atau PPnB

10). Penyerahan tidak dipungut kepada penerima fasilitas lainnya

11). Pengembalian PPN kepada orang pribadi pemegang paspor luar negeri

12). Penangguhan Bea Masuk

13). Pembebasan Bebas Masuk dan cukai

14). Keringanan Bea Masuk

Dari kedua pemaparan di atas dapat disimpulkan bahwa kedua nya memiliki fasilitas masing-masing yang dapat dipilih oleh calon pelaku usaha nantinya. Meskipun terdapat beragam argumen dan diragukan kesuksesannya, namun BP Batam menjamin bahwa kedua pilihan tersebut dapat menjadi terobosan bagi Batam dalam meningkatkan investasi. Hal inilah yang masih kurang dipahami banyak kalangan, umumnya di Batam bahwa FTZ dan KEK dapat menjadi pilihan bagi investor. Hanya bagaimana pemerintah menetapkan bentuk dan landasan hukumnya agar terdapat kepastian dan kejelasan, sehingga peluang yang ada dapat dimanfaatkan guna kesejahteraan masyarakat.

Hingga saat ini, FTZ dan KEK masih menjadi pilihan fasilitas investasi bagi calon pelaku usaha yang akan berinvestasi. Investor dapat memilih fasilitas mana yang membuat nyaman dan aman. Namun, disisi lain banyak investor yang bersikukuh berasumsi bahwa FTZ masih menjadi harapan dan model ekonomi yang sesuai dengan kondisi desain awal kawasan Batam ini dibentuk. Para pelaku usaha juga berharap bahwa pemerintah tidak perlu mengubah sistem FTZ yang sudah tertera dan sudah terlanjur dikenal sebagai image.

\section{Infrastruktur}

Dalam upaya mencapai tujuan pengembangan Batam sebagai daerah industri, prasyarat utama yang harus dipenuhi adalah pembangunan fisik dan nonfisik.

\section{a. Pembangunan Fisik}

Pembangunan fisik untuk memudahkan kelancaran investasi berupa insfrastruktur (jalan, jembatan flyover, pelabuhan laut, bandara, waduk, dsb), bangunan, dan fasilitas umum.

1). Waduk atau Dam (bendungan)

Seperti yang dipaparkan pada bab sebelumnya bahwa yang menjadi kendala utama di Batam adalah masalah air, karena air di Batam bersumber atau mengandalkan hanya dari air hujan. Tidak ada sungai, tidak ada air tanah/bor. Air hujan tadi ditampung di waduk (yang mana merupakan insfrastruktur BP Batam) air bersih yang befungsi untuk mandi, minum, dsb. 
Salah satu upaya yang dilakukan oleh Kementerian Pekerjaan Umum dan Perumahan Rakyat (PUPR) adalah dengan meningkatkan jumlah penampungan air di Indonesia, yaitu dengan membangun bendungan di Kelurahan Sijantung, Kecamatan Galang, Provinsi Kepulauan Riau. Hal ini dilakukan untuk mengantisipasi terdesaknya kebutuhan air baku yang akan meningkat, baik untuk domestik maupun industri di Kota Batam. Perkiraan defisit air yang akan dialami Batam dalam beberapa tahun ke depan diakibatkan jumlah penduduk yang semakin meningkat. Selain itu, tersedianya air baku merupakan hal vital bagi perkembangan Batam sebagai pusat pertumbuhan ekonomi.

Sebelumnya, Batam telah memiliki enam (6) waduk atau dam, yaitu dam Sei Ladi, dam Sei Harapan, dam Duriangkang, dam Tembesi, waduk Baloi dan waduk Nongsa. Upaya yang dilakukan Kementerian PUPR tersebut didukung oleh BP Batam, yaitu dengan membangun waduk Sei Gong. Pembangunan waduk ini telah direncanakan sejak tahun 2015 dan telah selesai pada tahun 2018 lalu dengan memakan anggaran pembangunan sebanyak Rp 238 miliar. Pembangunan ini menjadi proyek strategi nasional (PSN) yang dikerjakan oleh kotraktor PT Wika.

Waduk atau dam adalah salah satu solusi, karena sebagai daerah kepulauan sangat sulit menemukan waduk yang dapat dimanfaatkan untuk menampung air. Dengan demikian, mencari tempat pinggiran laut yang dapat dimanfaatkan dengan Estuari dam (pembendungan air hujan sebelum mengalir ke laut) adalah jalan keluar nya.

\section{2). Flyover atau jembatan layang}

Pembangunan Kota Batam yang semakin berkembang, membuat pemerintah gencar menambah dan memperbaiki aspek-aspek yang menjadi penunjang bagi perkembangan suatu daerah, seperti infrastruktur. Pada Desember 2017, telah dibangun sebuah jembatan layang Laluan Madani dengan panjang 460 meter, lebar 32 meter dan titik tertinggi dari permukaan tanah mencapai 9 meter di Simpang Jam, Batam, Kepulauan Riau. Anggaran yang dihabiskan untuk membangun jembatan layang ini adalah sebesar Rp 180 miliar. Rancangan pembangunan jembatan layang ini telah dibuat sejak Desember 2015. Berdirinya jembatan layang ini dioperasikan oleh Kementerian Pekerjaan Umum dan Perumahan Rakyat bekerjasama dengan BP Batam serta dikerjakan oleh PT Pembangunan Perumahan (PP) dimana harapannya adalah penambahan infrastruktur ini dapat mendorong pengembangan Kota Batam sebagai kawasan tujuan investasi dan menarik kunjungan wisatawan mancanegara.

\section{3). Mal Pelayanan Publik (MPP)}

Di akhir tahun 2017 tepatnya tanggal 7 Desember telah beroperasi salah satu infrastruktur yang akan melayani masyarakat Batam, yaitu Mal Pelayanan Publik (MPP). MPP ini berfungsi sebagai tempat penyelenggaraan pelayanan publik, seperti barang, jasa dan/atau administrasi dari instansi pemerintah maupun non instansi pemerintah dalam satu tempat. Sebelumnya, Menpan RB, Bapak Dr. H. Asman Abnur, S.E., M.Si melakukan studi banding ke negara Georgia yang kemudian dapat diterapkan di Indonesia dengan menunjuk Pilot Project Kota DKI Jakarta, Surabaya dan Batam. Hal ini dilakukan guna meningkatkan peringkat Ease of Doing Business (EoDB) atau kemudahan dalam berinvestasi di Indonesia.

Berdasarkan wawancara antara penulis dengan Bapak Imam terkait strategi BP Batam dalam menangani keluhan investor asing adalah bahwa didalam MPP telah disediakan sekitar 430 layanan, permohonan, dan sejenisnya. MPP merupakan bukti nyata keseriusan pemerintah guna meningkatkan pelayanan publik yang diresmikan di tahun 2018. Di Mal Pelayanan Publik terdapat klinik usaha, dimana investor asing dapat langsung menyampaikan problem yang dihadapi kemudian akan ditindaklanjuti oleh BP Batam.

\section{b. Pembangunan Non-Fisik}

Berbeda dengan pembangunan fisik, pembangunan non-fisik dilakukan untuk menarik minat investor, berupa kemudahan perizinan investasi.

\section{1). KLIK (Kemudahan Investasi Langsung Konstruksi)}

Nilai realisasi investasi asing di Batam yang tidak banyak mengalami progres dari tahun 2013 hingga 2014, membuat BP Batam selaku instansi pemerintah yang menangani perihal investasi asing harus terus 
menciptakan inovasi baru bagi para pelaku usaha. Mengingat bahwa salah satu kendala dari inevestor asing dalam berinvestasi terkait kemudahan investasi adalah pelayanan nya yang menghabiskan waktu yang cukup lama.

KLIK (Kemudahan Investasi Langsung Konstruksi) merupakan salah satu program BKPM yang diresmikan tahun 2016 guna mempermudah investor dalam pengerjaan konstruksi. Setelah memperoleh izin prinsip (IP), investor tidak perlu menunggu waktu yang lama dalam membangun proyek melalui KLIK. Adapun pengurusan perizinan pelaksana yang diperoleh, seperti izin mendirikan bangunan (IMB), izin lingkungan (AMDAL atau Analisis Mengenai Dampak Lingkungan) yaitu mengenai dampak negatif dan positif dari suatu rencana kegiatan/proyek yang dipakai pemerintah dalam menentukan apakah kegiatan tersebut layak atau tidak layak lingkungan. BKPM tidak memberi jumlah minimal nilai investasi yang harus ditanamkan oleh pelaku usaha. Namun, terlebih dahulu para investor harus memenuhi peraturan tata tertib kawasan industri atau disebut estate regulation. Sebelum perusahaan siap megeluarkan produk secara komersial, maka semua izin estate regulation harus dipenuhi. Selain BKPM tidak menetapkan jumlah minimal nilai investasi kepada investor, juga tidak membatasi terkait jumlah tenaga kerja sepanjang berlokasi di Kawasan Industri tertentu yang ditetapkan pemerintah.

Sejak diluncurkannya program layanan KLIK ini, nilai investasi di Batam meningkat. Dari yang sebelumnya di tahun 2015 sekitar US\$ 291.46 juta menjadi US\$ 463,73 juta di tahun 2016. Pertumbuhan investasi yang signifikan menunjukkan bahwa KLIK dipercaya oleh investor. Terdapat 5 perusahaan asing yang telah beroperasi dari 13 perusahaan yang masuk ke Batam, diantaranya PT Infocus Consumer International Indonesia yang memproduksi smartphone, PT Asus Teknologi Indonesia yang juga memproduksi smartphone ASUS serta PT Indo Kreasi Grafika yang memproduksi pengemasan dari kertas dan karton. Dengan adanya fasilitas kemudahan investasi KLIK ini dipercaya dapat mendongkrak investasi lebih banyak lagi yang masuk. Hal tersebut dikarenakan segala investasi berbasis kontruksi di kawasan Batam dan Bintan menjadi mudah dan efisien. Meskipun demikian, program KLIK ini hanya berlangsung hingga awal 2017.

\section{2). I23J (Izin Investasi 3 Jam)}

Upaya BP Batam dalam memperbaiki iklim dan keadaan bisnis dilakukan dengan menerapkan enam (6) strategi utama, yaitu untuk menjadikan Batam lebih kondusif dan menarik; memperbaiki insfrastruktur dan fasilitas; mempromosikan investasi lebih efektif, melaksanakan kebijakan-kebijakan secara konsisten dan transparan; melaksanakan tata kelola yang baik; dan menyediakan layanan bisnis yang inovatif.

Selain layanan KLIK, terdapat program layanan lain yang dibentuk oleh BKPM, yaitu i23J. Dalam perizinan dan persetujuan investasi, BP Batam adalah kota pertama di Indonesia untuk menerapkan program BKPM i23J (3-hours investment licensing) atau izin investasi 3 jam. BP Batam melanjutkan program dari BKPM ini untuk menarik banyak investor baik dalam maupun luar negeri dengan memberikan fasilitas yang akan memudahkan proses perizinan, yaitu i23J. Berbeda dengan layanan KLIK, untuk menggunakan layanan i23J, nilai minimum yang direncanakan untuk berinvestasi adalah sekitar 50 miliar Rupiah dan/atau menyerap setidaknya 300 tenaga kerja lokal dan surat permohonan harus di ajukan langsung paling tidak oleh satu (1) perwakian dari pemegang saham perusahaan yang diajukan.

Pada 1 September 2016, program i23J diresmikan di Batam tepatnya pada era kepemimpinan Hatanto Reksodipoetro di kantor BPM (Badan Penanaman Modal) Pelayanan Terpadu Satu Pintu (PTSP), Gedung Sumatera Promotion Center (SPC), Batam Center. Bagi pulau berbasis investasi seperti Batam, isu perizinan menjadi hal yang sangat krusial dimana investor menuntut kepastian. Dengan demikian, dibawah kepemimpinan Hatanto, BP Batam sudah seharusnya memberikan kepastian kepada calon investor salah satu caranya adalah dengan menggunakan layanan i23J.

Sejak peresemian perdana nya hingga pertengahan tahun 2017, telah ada sekitar 7 (tujuh) perusahaan yang menggunakan layanan i23J, diantaranya seperti Blackmagic Desain Manufacturing yang memproduksi terkait peralatan audio dan video, PT Enerco RPO International dalam industri pendukung minyak dan gas, PT LNG Easy Batam dalam industri pendukung minyak dan gas, serta PT Esun International Utama Indonesia terlibat dalam mendaur ulang logam dan non-logam menggunakan teknologi moderen dari Singapura. 
Keunikan dari inovasi BKPM yang dilanjutkan oleh BP Batam ini adalah dengan menggunakan layanan i23J, investor akan menerima "Produk 8". "Produk 8" adalah 8 perizinan yang akan langsung didapatkan oleh investor, diantaranya adalah :

1) Izin investasi

2) Akta perusahaan dan pengesahan

3) NPWP

4) Tanda Daftar Perusahaan (TDP)

5) Rencana Penggunaan Tenaga Kerja Asing (RPTKA)

6) Izin Mempekerjakan Tenaga Kerja Asing (IMTA)

7) Angka Pengenal Importir Produsen (API-P)

8) Nomor Induk Kepabeanan (NIK)

Penerapan layanan program i23J sangat mendorong nilai realisasi investasi asing di Batam. Pada tahun 2017, nilai realisasi investasi asing di Batam mencapai US\$ 618.74 juta setelah sebelumnya hanya mencapai US\$ 463,73 juta. Dengan inovasi baru yang diciptakan oleh BKPM dan dilanjutkan oleh BP Batam terbukti mendongkrak nilai investasi asing di Batam. Bahkan, BKPM berencana untuk membuat terobosan baru lainnya untuk terus meningkatkan nilai investasi aisng di Indonesia dengan memberikan kemudahan layanan investasi bagi calon investor.

\section{KESIMPULAN}

Setiap negara selalu memiliki upaya tersendiri dalam meningkatkan pembangunan dan kesejahteraan rakyat nya. Adapun salah satu upaya yang dilakukan adalah dengan menarik sebanyak mungkin investasi yang masuk. Investasi dipercaya dapat memperbaiki pertumbuhan perekonomian suatu negara. Indonesia salah satunya, negara berkembang yang membutuhkan adanya modal atau investasi jumlah besar untuk menuju industrialisasi. Dikeluarkannya Undang-Undang yang mengatur penanaman modal, baik dalam negeri maupun asing diharapkan dapat meningkatkan pertumbuhan ekonomi dan kesejahteraan rakyat nya. Agar dapat terwujud, maka perlu adanya iklim investasi yang kondusif.

Di Indonesia, memberikan kemudahan-kemudahan investasi oleh pemerintah kepada para pengusaha adalah upaya untuk 'mengabadikan' kekuasaan pemerintah, seperti dengan adanya bebas pajak, ijin khusus, dan lainnya. Hal ini disebut sebagai Crony Capitalism atau kapitalisme kroni yang dimaknai sebagai kapitalisme suatu negara yang dibentuk berdasarkan kedekatan para penguasa dengan pihak pemerintah. Kemudahankemudahan tersebut ditetapkan pula oleh pemerintah di tingkat lokal, seperti Batam yang kemudian menjadikan Indonesia berada pada posisi ke-7 dalam indeks Kapitalisme Kroni 2016 versi The Economist.

Posisi Batam yang startegis, yaitu berada di jalur lalu lintas perdagangan internasional Selat Malaka yang merupakan jalur perdagangan internasional tersibuk kedua setelah Selat Dover di Inggris dan berada dekat dengan negara yang tergolong maju, seperti Singapura menjadikannya sasaran investasi bagi para investor asing dari beberapa negara di dunia. Meskipun di tahun 2013-2014 nilai realisasi investasi asing terbilang rendah, upaya pemerintah pusat yang bekerjasama dengan pemerintah di Batam, yaitu Badan Pengusahaan Batam terus digesa. Badan Koordinasi Penanaman Modal terus berinovasi menciptakan program layanan kemudahan investasi serta memudahkan regulasi dalam menanamkan modalnya di Indonesia, tepatnya di Batam.

Hal ini dibuktikan dengan meningkatnya nilai realisasi investasi asing di tahun 2015 hingga 2017. Pergerakan nilai investasi asing di Batam di tahun 2015 lebih meningkat dari tahun sebelumnya, yang kemudian meningkat lebih drastis lagi di tahun 2016 hingga pada tahun 2017 dapat dikatakan bahwa tahun ini adalah puncak nya.

Terdapat dua (2) faktor yang menjadi penyebab meningkatnya investasi asing di Batam pada tahun 2015 hingga 2017, yaitu Deregulasi dan Infrastruktur. Dalam mendukung pemerintah untuk terus memperbaiki iklim investasi di Indonesia, Presiden Joko Widodo telah menekan Peraturan Presiden No. 91 Tahun 2017 Tentang Percepatan Pelaksanaan Berusaha pada akhir tahun lalu. Batam, memiliki dua pilihan fasilitas investasi, yaitu FTZ (Free Trade Zone) dan KEK (Kawasan Ekonomi Khusus) yang menjadi deregulasi dalam mendongkrak nilai investasi asing. Tujuan dari pembentukan FTZ ini adalah untuk meningkatkan investasi pada suatu daerah, dimana bea dan kuota dihapuskan dan kebutuhan untuk birokrasi ditekan rendah guna menarik 
perusahaan-perusahaan dengan menambahkan intensif kegiatan usaha. Pemerintah Pusat memberikan empat (4) keunggulan yang tercantum dalam Undang-Undang Pelabuhan Bebas dan Perdagangan Bebas, yaitu (1)Bebas Pajak Pertambahan Nilai (PPN), (2)Pajak Pertambahan Nilai Barang Mewah (PPN-BM), (3)Bea Masuk, dan (4)Bea Keluar.

Sementara, fasilitas lainnya seperti KEK hampir sama dengan FTZ, perbedaannya adalah bahwa KEK memiliki skala yang lebih kecil. KEK adalah pilihan fasilitas invetasi selain FTZ dimana bila investor berinvestasi melalui KEK barang yang dihasilkan dapat dikirim terlebih dahulu ke wilayah lain dalam negeri. Dengan menggunakan fasilitas KEK, calon investor akan mendapatkan 14 poin kemudahan, diantaranya 1). Investment Allowance, 2). Amortisasi dipercepat, 3). Pajak Dividen,4). Kompensasi kerugian yang lebih lama,5). Tax Holiday, 6). Fasilitas Pembebasan PPh Pasal 22 impor, 7). PPN impor tidak dipungut, 8). PPN pembelian dalam negeri tidak dipungut, 9). Pembebasan PPN dan atau PPnB, 10). Penyerahan tidak dipungut kepada penerima fasilitas lainnya, 11). Pengembalian PPN kepada orang pribadi pemegang paspor luar negeri, 12). Penangguhan Bea Masuk, 13). Pembebasan Bebas Masuk dan cukai, dan 14). Keringanan Bea Masuk.

Faktor penyebab meningkatnya investasi asing di Batam tahun 2015-2017 lainnya adalah infrastruktur. Dalam upaya mencapai tujuan pengembangan Batam sebagai daerah industri, prasyarat utama yang harus dipenuhi adalah pembangunan fisik dan nonfisik. Pembangunan fisik untuk memudahkan kelancaran investasi berupa insfrastruktur berupa penambahan jumlah waduk/dam, pembangunan flyover atau jembatan layang, dan Mal Pelayanan Publik (MPP). Sedangkan, pembangunan nonfisik dilakukan untuk menarik minat investor, berupa kemudahan fasilitas. Kemudahan fasilitas yang diciptakan oleh BKPM dan dilanjutkan oleh BP Batam adalah KLIK (Kemudahan Investasi Langsung Konstruksi) dan i23J (Izin Investasi 3 Jam). KLIK (Kemudahan Investasi Langsung Konstruksi) merupakan salah satu program BKPM yang diresmikan tahun 2016 guna mempermudah investor dalam pengerjaan konstruksi. Setelah memperoleh izin prinsip (IP), investor tidak perlu menunggu waktu yang lama dalam membangun proyek. Keunikan dari inovasi BKPM yang dilanjutkan oleh BP Batam ini adalah dengan menggunakan layanan i23J, investor akan menerima "Produk 8". "Produk 8" adalah 8 perizinan yang akan langsung didapatkan oleh investor, diantaranya adalah Izin investasi, Akta perusahaan dan pengesahan, NPWP, Tanda Daftar Perusahaan (TDP), Rencana Penggunaan Tenaga Kerja Asing (RPTKA), Izin Mempekerjakan Tenaga Kerja Asing (IMTA), Angka Pengenal Importir Produsen (API-P), dan Nomor Induk Kepabeanan (NIK).

Dengan demikian, faktor-faktor penyebab meningkatnya investasi asing di Batam tahun 2015 hingga 2017 diharapkan menjadi motivasi bagi pemerintah pusat dan daerah untuk terus menciptakan terobosan baru lainnya agar nilai investasi asing di Indonesia, tepatnya Batam terus signifikan. Mengingat Batam adalah salah satu kawasan industri di Indonesia yang menjadi target bagi investor asing. Selain infrastruktur yang memadai, kemudahan layanan inevstasi dan kepastian hukum sangat diperlukan bagi calon pelaku usaha.

Adapun saran yang dapat penulis sampaikan adalah :

1. Mengenai isu dualisme di Batam, sudah semestinya BP Batam dan Pemerintah Kota Batam saling bahumembahu dalam membangun Kota Batam meskipun memiliki peran dan fungsi yang berbeda-beda.

2. Dalam menjaga iklim investasi yang kondusif tidak hanya dengan membangun beragam infrastruktur, namun juga harus tetap memelihara dan mengawasi infrastruktur yang telah dibangun. Karena, terdapat beberapa titik di Kota Batam, utamanya jalan mengalami kerusakan seperti adanya lubang-lubang yang membuat siapapun yang melaluinya jadi tidak nyaman. Terlebih lagi jika hujan dan lubang-lubang tersebut tertutupi oleh genangan air hujan, tentu saja dapat membahayakan pengendara, utamanya pengendara sepeda motor.

3. BP Batam mungkin dapat menggunakan atau mempertahankan kebijakan-kebijakan yang sekiranya mampu meningkatkan nilai investasi asing di Batam untuk tahun-tahun berikutnya.

4. Kepala BP Batam seharusnya menjelaskan kepada masyarakat setempat maupun calon investor asing bahwa FTZ dan KEK adalah sebuah pilihan, sehingga dapat dipahami dan tidak salah dalam memberikan informasi.

Terkait tenaga kerja asing, Pemerintah Batam seharusnya dapat membatasi jumlah tenaga kerja asing yang akan dipekerjakan di Batam, seperti hanya tenaga ahli saja. Karena, masih banyak SDM lokal yang berkompeten dalam banyak bidang.

\section{DAFTAR PUSTAKA}


Badan Pengusahaan Kawasan Perdagangan Bebas dan Pelabuhan Bebas Batam (BP Batam) Nomor 10 Tahun 2011 tanggal 21 September 2011 tentang tugas dan fungsi BP Batam. Diakses di https://bpbatam.go.id/pages/read/52-tugas-dan-fungsi pada 20 September 2019.

Bagir Manan.2002. Pemerintahan Daerah Bagian I. Penerbit Penataan Administratif Organisation Planning. UGM. Yogyakarta.

E Journal Unsrat. Peran Pemerintah Kota Bitung dalam Peningkatan Investasi Asing di Sektor

Pariwisata. http://www.ejournal.unsrat.ac.id/index.php/polotico/article/download/10310 diakses pada $19 \quad$ September 2019.

Edy Putra Irawady. Kepala BP Batam tahun 2019. Sarjana S1 bidang Hukum dari UI (1981). Meraih gelar Master of Arts in International Graduate Transaction dari George Mason

University, Amerika Serikat.

Fitzgerald, E.V.K, 1978. Public Sector Investment Planning for Developing Country. First Edition, The MacMillan India Press Ltd, Madras.

Grigg, N. 1998. Infrastructure Engineering and Management. John Wiley \& Sons.

HAW Widjaja. 2005. Penyelenggaraan Otonomi di Indonesia Dalam Rangka Sosialisasi UndangUndang Nomor 32 Tahun 2004 tentang Pemerintahan Daerah. Jakarta: Raja Grafindo, hlm. 133.

Investor Punya dua Pilihan Fasilitas investasi di Batam. https://www.aa.com.tr/id/ekonomi/investorpunya-dua-pilihan-fasilitas-investasi-di- batam/1409492

Kodoatie, Robert J. 2005. Pengantar Manajemen Infrastruktur. Pustaka Pelajar : Yogyakarta.

Kuncoro, M. 2005. "Menanti Reformasi Iklim Bisnis Indonesia". Jurnal Ilmu-Ilmu SosialUNISIA, No. 55/XXVIII///2005

Kuncoro, Mudrajat. 2010. Dasar-Dasar Ekonomika Pembangunan, UPP STIM YKPN Yogyakarta.

Krugman and Obsfeld. 2003. International Economics, Theory and Policy. Sixth Edition. Boston.

Mankiw, N. Gregory. 2003. Teori Makro Ekonomi. Jakarta : Erlangga.

MEDIA KEUANGAN. Transparansi Informasi Kebijakan Fiskal. 2018. Vol. XIII/No.128. diakses dari https://www.kemenkeu.go.id/media/9830/media-keuangan-mei- 2018.pdf

Muliono, Heri. Op. Cit., halaman 117-118.

Purba, D. 2018. Faktor Dominan Penurunan Pertumbuhan Ekonomi Batam. Seminar Nasional Ilmu Sosial dan Teknologi (SNISTEK) 1, 23 Agustus 2018. Batam. Indonesia.

Pusat Pengelolaan Data dan Sistem Informasi (PDSI) BP Batam. Batam Indonesia Free Trade Zone Authority BP Batam. Tahun 2018. Edisi II Vol. XXXIV. Hlm. 10

Wresniwiro. 2012. Membangun Republik Desa. Jakarta. Visimedia. 